\title{
STRATEGI PEMASARAN PRODUK PINJAMAN PADA CREDIT UNION
}

\author{
Paulus \\ Fakultas Ilmu Sosial dan Ilmu Politik Universitas Kapuas \\ paulus_semari@yahoo.com
}

\begin{abstract}
Abstrak : Penelitian ini mengkaji permasalahan mengenai strategi pemasaran produk pinjaman (kredit) pada lembaga keuangan Credit Union (CU) dengan mengambil tempat penelitian pada CU Keling Kumang Kantor Cabang Putussibau. Tujuan penelitian ini adalah untuk Mendiskripsikan dan mengetahui Pelaksanaan strategi Pemasaran yang meliputi produk (Product), harga (Price), tempat (Place), dan promosi (Promotion). Hasil penelitian menunjukkan bahwa aspek produk memiliki keunggulan karena produk pinjaman ada 6 jenis untuk mengakomodir kebutuhan anggota, namun masih ada keinginan anggota yang belum terpenuhi yaitu jenis pinjaman untuk pasca panen. Aspek harga yaitu variasi bunga pinjaman yang diterapkan ada dua metode perhitungan yaitu sistem bunga flat dan sistem bunga anuitas dengan kisaran bunga antara $1 \%$ sampai $2 \%$ sesuai dengan jenis pinjaman. Aspek tempat CU Keling Kumang sudah memiliki kantor yang representatif untuk pelayanan anggota dan untuk aktivitas administrasi, namun daerah pelayanan yang jauh masih menjadi kendala dalam pelayanannya mengingat jarak tempuh dan sulitnya medan yang dilalui. Aspek promosi, CU Keling Kumang sudah menerapkan promosi dengan berbagai metode, dan metode yang sering digunakan adalah dengan pemberian brosur - brosur tentang produk. Pemasangan spanduk, ikut serta di dalam pameran-pameran dan kegiatan pendidikan anggota secara terjadwal setiap tahun bukunya.
\end{abstract}

Kata Kunci : Strategi, Pemasaran, Produk, Pinjaman

\section{LATAR BELAKANG}

Sejak jaman reformasi Koperasi semakin diperhatikan oleh pemerintah sebagai salah satu sektor yang berperanan penting untuk mendongkak perekonomian, khusus perekonomian rakyat di pedesaan. Bangsa Indonesia yang merupakan negara kepulauan sebagian besar merupakan daerah pedesaan dimana desa sebagai garda terdepan sebagai basis berkembangnya usaha koperasi. Credit Union atau yang biasa disingkat $\mathrm{CU}$, merupakan usaha yang berbadan hukum koperasi yang berkembang pesat di Kalimantan Barat dan hampir di semua wilayah mulai dari perkotaan sampai ke pelosok desa CU ada. Perkembangan $\mathrm{CU}$, selain dukungan dari pemerintah juga tidak terlepas dari peran serta masyarakat dalam bentuk partisipasi sebagai anggota yang aktif sesuai dengan peraturan $\mathrm{CU}$ serta terus - menerus memberikan sosialisasi, motivasi, kepada masyarakat yang lain supaya mereka yang belum mengenal menjadi tahu dan memahami dengan begitu setelah memahami dan sadar akan pentingnya masa depan yang lebih baik dapat bergabung menjadi anggota yang selanjutnya dapat merubah sedikit demi sedikit taraf hidupnya melalui CU.

Credit Union (CU) merupakan lembaga keuangan non bank yang memiliki keunikan tersendiri bila dibandingkan dengan model-model koperasi lain yang ada di Indonesia. Pendirian CU yang dimulai dari penyadaran akan pentingnya kerjasama untuk saling tolong - menolong dan keyakinan akan kekuatan bersama menjadikan pendidikan, swadaya, dan solidaritas sebagai pilar utama yang harus di kedepankan dalam mengembangkan usaha Credit Union. Selain itu perinsip utama yang perlu ditanamkan baik di koperasi umumnya dan CU khususnya yaitu kepercayaan. CU dibangun diatas pondasi kepercayaan dan kerja sama, tanpa kepercayaan tidak mungkin ada kerja sama, sehingga penting untuk menjaga agar antar anggota, dan segenap aktivis CU untuk selalu memberikan kontribusi secara maksimal sehingga dapat terwujudnya pelayanan yang prima.CU Keling Kumang memiliki Badan Hukum dengan Nomor 50b/BH/PAD/X/ 
201, Sehubungan dengan pelayan kepada masyarakat dan anggota khususnya, Credit Union Keling Kumang menyediakan berbagai produk layanan keuangan yang tentunya bertujuan untuk mengakomodir semua tuntutan dan kepentingan masyarakat dalam hal keuangan yang tujuan akhirnya adalah untuk meningkatkan taraf hidup anggota sehingga mandiri dalam bidang keuangan. Program dan strategi pengembangan organisasi sebagai implikasi dari hasil Rapat Anggota Tahunan (RAT), yang merupakan kekuasaan tertinggi di koperasi harus diformulasikan dan disampaikan secara jelas dan terbuka kepada semua pengurus, pengawas dan tim manajemen yang selanjutnya dapat dilaksanakan dengan baik.

Produk - produk layanan keuangan yang di sediakan oleh CU Keling Kumang secara umum tidak berbeda jauh dengan produk CU pada umumnya, namun tentunya terdapat perbedaan perbedaan yang menjadi ciri khas dan merupakan competitive advantage (keunggulan bersaing) terutama dalam hal inovasi produk dan pelayanan. Produk tabungan dan pinjaman (kredit) merupakan jenis produk utama yang dari sejak awal dikembangan dengan berbagai jenis tabungan dan produk pinjaman yang ada sesuai dengan keinginan masyarakat. Sesuai dengan keinginan masyarakat artinya bahwa produk-produk yang ada tercipta karena aspirasi dari masyarakat dan anggota yang tertuang dalam rapat anggota, aspirasi tersebut diakomodir oleh Pengurus, dan selanjutkan diformulasikan dalam bentuk pola kebijakan pengurus, sehingga produk yang ada terus dikembangkan secara inovatif dan berkelanjutan. Selain produk tabungan dan pinjaman masih banyak lagi jenis layanan yang lain, baik layanan keuangan maupun sosial.

Produk pinjaman (kredit) merupakan salah satu produk unggulan dan merupakan urat nadi dalam bisnis keuangan CU sehingga harus dikelola secara profesional dan harus diorganisir secara sistematis di dalam ruang lingkup manajemen perkreditan. Berbagai tantangan dan perubahan baik berasal dari internal maupun eksternal harus dapat disikapi dan dilakukan sistem manajemen yang profesional dan terintegrasi mulai dari perencanaan, pengorganisasian, pelaksanaan, dan pengawasan. Perkembangan suatu organisasi atau perusahaan dalam hal ini kemajuan lembaga $\mathrm{CU}$ dapat dilihat dari indikator standar kinerja keuangan. Salah satu aspek penting yang menjadi indikator keberhasilan CU adalah aspek kredit (pinjaman). Adapun jenis - jenis pinjaman yang ada di CU Keling Kumang antara lain 1) pinjaman Produktif, 2) pinjaman konsumtif, 3) pinjaman KPR (Kredit Pemilikan Rumah), 4) Pinjaman Pendidikan, 5) Pinjaman Kapitalisasi (pinjaman untuk menambah tabungan), dan 6) Pinjaman Rebung (rendah bunga). Pinjaman merupakan urat nadi usaha $\mathrm{CU}$, karena dari usaha peredaran pinjaman inilah CU mendapatkan penghasilan berupa keuntungan dari bunga pinjaman. Kajian mengenai pinjaman ada dua persoalan yang dapat terjadi yaitu jumlah uang yang beredar berupa piutang dan kualitas piutang tersebut. CU memiliki standar khusus mengenai berapa rasio pinjaman beredar seharusnya dan standar mengenai ambang batas kredit bermasalah atau lalai.

Produk pinjaman merupakan produk jasa yang dikembangan oleh berbagai lembaga keuangan baik bank maupun lembaga keuangan non bank seperti halnya Credit Union. Berdasarkan asal katanya pengertian pinjaman (kredit) adalah penyerahan sejumlah uang dari pemberi kredit yang disebut kreditur kepada penerima uang yang disebut peminjam atau disebut juga debitur yang diikat dalam suatu perjanjian kredit berupa jumlah uang, tingkat bunga, jangka waktu, dan jaminan. Sementara definisi kredit menurut Undang-Undang Nomor 10 Tahun 1998 tentang perbankan adalah penyediaan uang atau tagihan yang dipersamakan dengan itu, berdasarkan persetujuan atau kesempatan pinjam meminjam antara pihak penyandang dana dengan pihak lain yang mewajibkan pihak lain untuk melunasi utangnya setelah jangka waktu tertentu dengan jumlah bunga, imbalan atau pembagian hasil keuntungan".

Berdasarkan pengertian diatas, maka dapat dijelaskan lebih lanjut mengenai pengertian kredit, yaitu :Adanya dua pihak yang saling 
berkepentingan, yaitu pihak penyedia uang (kreditur) dan pihak peminjam uang (debitur). Kedua pihak tersebut melaksanakan atas perjanjian pinjam meminjam, dimana keduanya harus mematuhi semua syarat dan kewajiban masingmasing.Terdapat suatu penyerahan uang, tagihan atau juga dapat berupa barang yang menimbulkan tagihan kepada pihak lain, dengan harapan CU sebagai kreditur akan memperoleh suatu tambahan nilai dari pokok pinjaman tersebut yang berupa uang, imbalan atau pembagian hasil keuntungan.Terjadi suatu kesepakatan bersama tentang pelunasan utang, jangka waktu dan jaminan serta jumlah bunga, imbalan maupun pembagian hasil keuntungan yang akan diselesaikan dalam jangka waktu tertentu.

Kredit yang diberikan kepada debitur berdasarkan pada kepercayaan, bahwa pihak anggota dapat mengembalikan kredit yang diterimanya sesuai dengan jangka waktu yang telah ditetapkan berikut syarat-syarat yang telah disetujui oleh kedua pihak. Menurut Kasmir (2013 : 114 115) terdapat unsur - unsur yang harus dipenuhi di dalam transaksi pinjaman (kredit) yaitut : Kepercayaan. Kepercayaan merupakan suatu keyakinan bagi si pemberi kredit bahwa kredit yang diberikan (baik berupa uang, barang atau jasa) benar - benar diterima kembali di masa yang akan datang sesuai jangka waktu kredit. Kesepakatan. Kesepakatan dituangkan dalam suatu perjanjian dimana masing-masing pihak menandatangani hak dan kewajibannya masing-masing. Kesepakatan dituangkan dalam akad kredit dan ditandatangani kedua belah pihak sebelum kredit dikucurkan. Jangka waktu. Setiap kredit yang diberikan memiliki jangka waktu tertentu, jangka waktu ini mencakup masa pengembalian kredit yang telah disepakati. Resiko. Akibat adanya tenggang waktu, maka pengembalian kredit akan memungkinkan suatu risiko tidak tertagihnya atau macetnya pemberian suatu kredit. Semakin panjang suatu jangka waktu kredit, maka semakin besar risikonya, demikian pula sebaliknya. Balas jasa. Balas jasa merupakan keuntungan atau pendapatan atas pemberian suatu kredit.
Keberhasilan dalam pendistribusikan pinjaman kepada anggota dipengaruhi oleh berbagai faktor terutama kualitas produk pinjaman, sehingga mempengaruhi minat atau selera konsumen atau anggota, kemudian harga atau pengorbanan yang harus anggota bayar untuk mendapatkan pinjaman, selanjutnya tempat dilakukan transaksi pinjaman, dan terakhir adalah kegiatan promosi untuk memperkenalkan dan menumbuhkan minat masyarakat dan anggota. Suatu sistem usaha yang dipengaruhi oleh aspek produk, harga, tempat dan promosi disebut dengan Bauran Pemasaran (marketing Mix). Menurut Djaslim Saladin (2007:3) Bauran Pemasaran adalah "serangkaian dari variabel pemasaran yang dapat dikuasai oleh perusahaan dan digunakan untuk mencapai tujuan dalam pasar sasaran". Sedangkan menurut Kotler yang dialihbahasakan oleh Benyamin Molan (2007:23), Bauran Pemasaran adalah "seperangkat alat pemasaran yang digunakan perusahaan untuk mencapai tujuan pemasarannya". Kotler yang dialihbahasakan oleh Benyamin Molan (2007:17) mengklasifikasikan empat unsur dari alat-alat bauran pemasaran yang terdiri atas $4 \mathrm{P}$ dalam pemasaran, adalah : produk (product), harga (price), tempat (place), dan promosi (promotion).

\section{Produk (product)}

Produk adalah segala sesuatu baik yang bersifat fisik maupun non fisik yang dapat ditawarkan kepada konsumen untuk memenuhi keinginan dan kebutuhannya. Produk merupakan unsur terpenting dalam bauran pemasaran yang memiliki berbagai macam arti dan makna, namun secara umum produk adalah segala sesuatu yang dapat ditawarkan ke pasar untuk diperhatikan, dibeli, digunakan dan dikonsumsi oleh pengguna pemakai. Istilah produk mencakup benda fisik, jasa, kepribadian, tempat, organisasi, atau ide. Keputusan-keputusan mengenai produk mencakup kualitas, kestimewaan, jenis merk, kemasan, pengembangan, berdasarkan penelitian pasar, pengujian dan pelayanan pra dan purna jual. Produk menurut Stanton yang dikutip oleh Alma (2007:139), merupakan seperangkat atribut baik berwujud 
maupun tidak berwujud, termasuk di dalamnya masalah warna, harga, nama baik pabrik, nama baik toko yang menjual (pengecer), dan pelayanan pabrik serta pelayanan pengecer yang diterima oleh pembeli guna memuaskan keinginannya.

Banyak orang berpikir bahwa sebuah produk merupakan tawaran berwujud, namun produk sebenarnya memiliki dimensi yang lebih daripada itu. Produk menurut Kotler dan Keller (2009:4) adalah sesuatu yang dapat ditawarkan ke pasar untuk memuaskan kebutuhan atau keinginan. Produk - produk yang dipasarkan meliputi barang fisik, jasa, pengalaman, acaraacara, orang, tempat, properti, organisasi, dan gagasan. Istilah lain dari produk yaitu seperti penawaran dan pemecahan. Produk atau penawaran dapat dibedakan menjadi 3 jenis yaitu barang fisik, jasa, dan pemecahan. Tingkat kepentingan produk fisik lebih tergantung kepada jasa yang mereka berikan daripada kepemilikannya. Menurut Laksana (2008 : 67), termasuk dalam pengertian produk, yaitu : Good; barang - barang fisik. Services; Jasa/pelayanan yang bersifat non fisik, yang menyertai atau tidak menyertai produk barang fisik. Experiences; Pengalaman kegiatan atau seseorang yang dapat dinikmati oleh orang lain. Events; kegiatan atau peristiwa yang dibutuhkan oleh orang banyak. Persons; keahlian atau ketenaran seseorang. Places; Tempat atau kota yang memilliki keunggulan, keunikan atau keindahan. Properties; Hak kepemilikan bisa berupa benda nyata (realestate) atau finansial (saham dan obligasi). Organizations; Lembaga atau wadah yang dapat memberikan citra atau nilai jual dari suatu produk. Information; Informasi yang dapat diproduksi dan dipasarkan. Ideas; gagasan yang menghasilkan produk yang diminati oleh konsumen.

Konsep produk adalah salah satu konsep bisnis tertua. Konsep produk menyatakan bahwa konsumen akan lebih menyukai produk yang tersedia secara luas dan murah. Para menajer perusahaan yang berorientasi produk berkonsentrasi untuk mencapai efisiensi produksi yang tinggi, biaya rendah, dan distribusi secara masal. Mereka mengasumsikan bahwa konsumen terutama tertarik pada ketersediaan produk dan harga yang rendah. Orientasi itu sangat cocok di negara-negara berkembang dimana konsumen lebih tertarik untuk mendapatkan produk daripada fiturnya. Orientasi itu juga berguna ketika perusahaan ingin memperluas pasar. Menurut Nasution (2004: 31), Kecocokan dalam menggunakan suatu produk adalah apabila produk mempunyai daya tahan penggunaannya yang lama, produk yang digunakan akan meningkatkan citra atau status konsumen yang menggunakannya, produk tidak mudah rusak, adanya jaminan kualitas (quality assurance) dan sesuai etika bila digunakan. Kecocokan penggunaan produk seperti dikemukakan di atas memiliki dua aspek utama, yaitu ciri-ciri produknya memenuhi tuntutan penggunaan dan tidak memiliki kelemahan.

Adapun aspek tersebut diantaranya adalah : Ciri-ciri produk yang memenuhi permintaan pelanggan. Produk berkualitas, memiliki ciri yang khusus atau istimewa, berbeda dari produk pesaing dan dapat memenuhi harapan atau tuntutan sehingga dapat memuaskan pelanggan. Kualitas yang lebih tinggi memungkinkan perusahaan meningkatkan kepuasan pelanggan, membuat produk laku terjual, dapat bersaing dengan pesaing, memperluas wilayah pemasaran, dan volume penjualan serta dapat dijual dengan harga yang lebih tinggi. Bebas dari kelemahan. Suatu produk dapat dikatakan berkualitas tinggi apabila di dalam suatu produk serta unsur yang terdapat didalamnya tidak terdapat kelemahan, tidak terdapat cacat sedikitpun. Kualitas yang tinggi menyebabkan perusahaan dapat mengurangi tingkat kesalahan, mengurangi pengerjaan kembali dan pemborosan, mengurangi pembiayaan terhadap klaim garansi, mengurangi ketidakpuasan pelanggan, mengurangi inspeksi dan pengujian, mengurangi waktu pengiriman produk ke pasar, meningkatkan hasil (yield) dan meningkatkan utilisasi kapasitas produksi, serta memperbaiki kinerja penyampaian produk.

Crosby dalam M. Nasution (2004: 35), menyatakan bahwa kualitas adalah conformance to requirement, yaitu sesuai dengan yang diisyaratkan atau di standarkan. Suatu produk 
memiliki kualitas apabila sesuai dengan standar kualitas yang telah ditentukan. Standar kualitas meliputi bahan baku, proses produksi, dan produk jadi. Feigenbaum, dalam M. Nasution (2004:43), menyatakan bahwa kualitas adalah suatu kondisi dinamis yang berhubungan dengan produk, manusia/tenaga kerja, proses dan tugas, serta lingkungan yang memenuhi atau melebihi harapan pelanggan atau konsumen. Meskipun tidak ada definisi kualitas yang diterima secara universal, namun pengertian kualitas di atas terdapat beberapa persamaan, yaitu sebagai berikut: Kualitas mencakup usaha memenuhi atau melebihi harapan pelanggan. Kualitas merupakan kondisi yang selalu berubah. Setelah melihat definisi di atas, maka kualitas produk mengacu pada bagaimana produk tersebut menjalankan fungsinya yang mencakup keseluruhan dari produk, yaitu berupa ketahanan, kehandalan, ketepatan, kemudahan dalam pengoperasian, dan kemudahan dalam perbaikan serta atribut-atribut nilai lainnya. Penetapan kualitas merupakan salah satu cara untuk memenangkan persaingan di pasar, karena mutu merupakan salah satu cara penempatan suatu produk di benak pelanggan.

Garvin Dalam M. Nasution (2006:55) mengemukakan delapan dimensi kulitas yang dapat digunakan sebagai variabel kualitas suatu produk yang diukur dan digunakan sebagai kerangka perencanaan strategis. Adapun dimensi kualitas yang dikemukakan yaitu sebagai berikut, Performance (Kinerja), karakteristik operasi pokok dari produk inti (core Proudct). Features (Ciri-ciri atau keistimewaan tambahan), yaitu karakteristik sekunder atau pelengkap. Reliability (Kehandalan), kemampuan perusahaan dalam memberikan kualitas produk yang sesuai dengan harapan konsumen. Conformance to specification (Kesesuaian dengan spesifikasi), yaitu sejauh mana karakteristik desain dan operasi memenuhi standar-standar yang telah ditetapkansebelumnya. Durability (Daya tahan), berkaitan dengan berapa lama suatu produk dapat terus digunakan. Serviceability, meliputi kecepatan, kompetensi, kenyamanan, mudah direparasi, serta penangan keluhan yang memuaskan. Aesthetics (Estetika), daya tarik produk terhadap panca indera, seperti bentuk fisik, warna, dan sebagainya. Perceived quality (Kualitas yang dipersepsikan), yaitu citra dan reputasi produk serta tanggungjawab perusahaan terhadapnya. Biasanya karena kurangnya pengetahuan pembeli akan atribut / ciri-ciri produk yang akan dibeli, maka pembeli mempersepsikan kualitasnya dari aspek harga, nama merk, iklan, dan reputasi perusahaan.

\section{Harga (Price)}

Harga merupakan sejumlah uang yang diperlukan sebagai penukar berbagai kombinasi produk dan jasa, dengan demikian harga berhubungan dengan bermacam-macam barang dan atau jasa (pelayanan). Harga merupakan unsur terpenting kedua dalam bauran pemasaran setelah produk dan merupakan satu-satunya unsur dalam bauran pemasaran yang menghasilkan pendapatan penjualan, sedangkan unsur-unsur lainnya merupakan pengeluaran biaya saja. Keputusankeputusan mengenai harga mencakup tingkat harga, potongan harga, keringanan periode pemasaran, dan rencana iklan yang dibuat oleh produsen. Harga menurut Yoeti dalam Hurriyati (2008:51) harga dapat diartikan sebagai suatu jumlah uang yang harus dipersiapkan seseorang untuk membeli atau memesan suatu produk yang diperlukan atau diinginkannya. Penentuan harga merupakan titik kritis dalam bauran pemasaran karena harga menentukan pendapat dari suatu usaha. Disamping itu juga harga merupakan satu-satunya unsur bauran pemasaran yang merupakan penerimaan penjualan, sedangkan unsur lainnya merupakan unsur biaya apa saja. Keputusan penentuan harga juga sangat signifikan dalam penentuan nilai atau manfaat yang dapat diberikan kepada pelanggan dan memainkan peranan penting dalam gambaran kualitas produk.

Menurut Alma (2007 : 169) bahwa harga adalah nilai suatu barang atau jasa yang dinyatakan dengan uang. Demi mendapatkan sebuah barang atau jasa yang diinginkan seorang konsumen harus menukarkan uang dengan barang atau jasa tersebut. Harga merupakan variabel yang 
independen dalam pemasaran produk jasa khususnya produk tabungan, artinya faktor harga sangat tergantung dari faktor - faktor lainnya terkait dengan besar biaya yang dikeluarkan untuk menghasilkan atau menghadirkan suatu produk untuk siap dipasarkan. Biasanya sesuai dengan hukum ekonomi, semakin tinggi harga produk yang ditawarkan semakin rendah permintaan akan produk tersebut, begitu juga sebaliknya. Metode penetapan harga merupakan suatu keputusan yang penting di dalam pemasaran produk. Menurut $\mathrm{H}$. Oka A. Yoeti dalam ratih Hurriyati (2008 : 58) ada tiga cara sederhana untuk menetapkan harga, yaitu : Skim The Cream, atau disebut juga dengan istilah Premium Pricing. Berdasarkan cara ini harga ditetapkan setinggi mungkin tanpa menghiraukan keluhan konsumen. Going rate pricing atau Average Rate Pricing, dimana penetapan harga berdasarkan harga rata - rata produk lain. Penetration Pricing, yaitu harga suatu produk ditetapkan di bawah harga rata - rata produk lain. Menurut Alex D. Tryana (1985 :26), untuk memilih tiga alternatif harga diatas, sangat tergantung faktor - faktor berikut, yaitu : Tergantung dari tujuan perusahaan, apakah berorientasi pada profit atau pangsa pasar yang luas. Besar kecilnya biaya produksi untuk menghasilkan produk tersebut. Tergantung daya beli target pasar yang dijadikan sasaran pemasaran. Keadaan persaingan yang terjadi di pasar saat itu. Kualitas produk itu sendiri, diatas, sedang atau di bawah yang lain. Apakah perusahaan penghasil produk termasuk seorang "leader" di pasar atau hanya sebagai "follower" saja. Tergantung dari merek atau brand image perusahaan yang menghasilkan produk itu. Kondisi perekonomian dimana produk itu dipasarkan. Peraturan pemerintah, bila bisnis itu diatur secara ketat oleh pemerintah.

Menurut Kotler (2004 : 256) tinggi atau rendahnya harga suatu produk akan tergantung pada faktor-faktor sebagai berikut :Permintaan. Permintaan konsumen terhadap suatu produk tinggi biasanya merupakan indikator bahwa daya beli konsumen tinggi. Dengan kondisi demikian maka harga akan dapat ditetapkan secara maksimal.Biaya. Penetapan harga secara minimal sebatas tingkat biaya produksi yang dikeluarkan oleh perusahaan termasuk memperhatikan juga kondisi perekonomiannya. Persaingan. Faktor persaingan dapat menyebabkan tingkat harga berada diantara dua ekstrem yaitu pada tingkat ekstrem terendah (ekstrem minimal) dan pada tingkat harga tertinggi (ekstrem maksimal). Jika pada suatu kondisi daya beli masyarakat tetap tinggi, tetapi perusahaan dihadapkan pada persaingan maka perusahaan tersebut harus menyesuaikan terhadap kondisi persaingan yang dihadapi. Kebijakan Pemerintah. Faktor kebijakan pemerintah kadang kala menjadi kendala dalam penetapan harga standar. Berkaitan dengan kebijakan pemerintah adalah faktor tanggung jawab sosial perusahaan. Pemerintah mengambil kebijakan dalam mengendalikan harga dari perusahaan dengan alasan utama dalam bauran pemasaran yang menghasilkan penjualan. Oleh sebab itu penetapan harga, perlu strategi artinya tidak terlalu tinggi dan juga tidak terlalu rendah.

\section{Tempat (Place)}

Istilah tempat (place) sama artinya dengan saluran pemasaran yaitu menunjukkan berbagai kegiatan yang dilakukan oleh produsen untuk menjadikan suatu produk yang dihasilkan dapat diperoleh dan tersedia bagi konsumen pada waktu dan tempat yang tepat dimanapun konsumen berada. Menurut Ratih Hurriyati (2008:55) tempat diartikan sebagai tempat pelayanan yang digunakan dalam pemasok kepada pelanggan yang dituju merupakan keputusan kunci. Keputusan mengenai lokasi pelayanan yang akan digunakan melibatkan pertimbangan dimana penyerahan jasa kepada pelanggan dan dimana itu akan berlangsung. Tempat juga penting sebagai lingkungan dimana dan bagaimana suatu produk akan diserahkan sebagai bagian dari nilai dan manfaat. Menurut Kotler (1996: 40) tempat atau distribusi (place) adalah "berbagai kegiatan yang dilakukan perusahaan untuk membuat produknya mudah diperoleh dan tersedia untuk konsumen sasaran" (the various the company understakes to make product accessible and available to target customer). Keputusan penentuan lokasi dan 
saluran yang digunakan untuk memberikan jasa kepada pelanggan melibatkan pemikiran tentang bagaimana cara mengirimkan atau menyampaikan jasa kepada pelanggan dan dimana hal tersebut akan dilakukan. Sebagai salah satu variabel marketing, tempat (place) memegang peranan penting dalam membantu perusahaan memastikan produknya, karena tujuan dari distribusi adalah menyediakan barang dan jasa yang dibutuhkan dan diinginkan oleh konsumen pada tempat dan waktu yang tepat. Penentuan lokasi untuk pemasaran juga mempengaruhi jumlah volume penjualan produk yang dihasilkan sebuah perusahaan. Oleh karena itu, sebuah perusahaan akan mencari lokasi yang strategis untuk digunakan sebagai lokasi produksi maupun lokasi distribusinya. Apabila berdasarkan survei pasar telah diketahui daerah-daerah potensial sebagai tempat produk yang dihasilkan perusahaan, maka yang terpenting adalah menentukan daerah-daerah strategis tempat para perantara membantu menyalurkan barang hingga sampai ke tangan konsumen.

\section{Promosi (Promotion)}

Promosi merupakan berbagai kegiatan yang dilakukan perusahaan dengan tujuan utama untuk menginformasikan, membujuk, mempengaruhi dan mengingatkan konsumen agar membeli produk dari perusahaan. Dalam hal ini keputusan-keputusan yang diambil mencakup iklan, penjualan personal, promosi penjualan, dan publikasi.

Pemasaran memerlukan alat komunikasi yang berguna untuk memperkenalkan produknya kepada pasar sasaran. Promosi merupakan alat komunikasi antara produsen dan konsumen. Menurut Alma (2007:179) "promosi merupakan sejenis komunikasi yang memberikan penjelasan yang meyakinkan calon konsumen tentang barang dan jasa. Tujuan promosi adalah memperoleh perhatian, mendidik, mengingatkan, dan meyakinkan calon konsumen". Perusahaaan juga sering menggunakan teknik promosi penjualan seperti pameran dan peragaan sebagai bagian dari Promotion Mix untuk barang industri. Kegiatan promosi yang banyak dipakai untuk barang konsumsi adalah promosi penjualan, seperti kupon berhadiah, peragaaan di toko pengecer, dan periklanan. Bagi perusahaan jasa seperti lembaga keuangan, khususnya koperasi simpan pinjam, promosi dapat dilakukan melalui siaran radio, melalui pembagian brosur-brosur, dan pelaksanaan pendidikan bagi anggota serta kunjungan dari rumah ke rumah.

Menurut Kotler (1996 : 49) bahwa "fungsi promosi dalam bauran pemasaran adalah untuk mencapai berbagai tujuan komunikasi dengan setiap konsumen". Promosi berarti kegiatan mempengaruhi calon konsumen supaya mengetahui dan selanjutnya tertarik terhadap produk yang ditawarkan. Proses mempengaruhi calon pembeli ini memerlukan kemampuan komunikasi yang memadai. Selanjutnya menurut Gitosudarmo (2001 : 214), promosi adalah kegiatan yang ditujukan untuk mempengaruhi konsumen agar mereka menjadi kenal akan produk yang ditawarkan oleh perusahaan kepada mereka dan kemudian mereka menjadi senang lalu membeli produk tersebut. Gitosudarmo (2001 : 216) menambahkan bahwa alat-alat yang dapat dipergunakan untuk mempromosikan produknya pengusaha dapat memilih beberapa cara yaitu : Advertensi (periklanan), merupakan alat utama bagi pengusaha untuk mempengaruhi konsumennya. Advertensi ini dapat dilakukan oleh pengusaha lewat surat kabar, radio, majalah, bioskop, televisi ataupun dalam bentuk posterposter yang dipasang di pinggir jalan atau tempattempat yang strategis. Promosi Penjualan (Sales Promotion), merupakan kegiatan perusahaan untuk menjajakan produk yang dipasarkannya sedemikian rupa sehingga konsumen akan mudah untuk melihatnya dan bahkan dengan cara penempatan dan pengaturan tertentu maka produk tersebut akan menarik perhatian konsumen. Penjualan Pribadi (Personal Selling), merupakan kegiatan perusahaan untuk melakukan kontak langsung dengan para calon konsumennya. Dengan kontak langsung ini diharapkan akan terjadi hubungan atau interaksi yang positif antara pengusaha dengan calon konsumennya. Kontak langsung akan dpata mempengaruhi secara lebih 
intensif para konsumennya karena dalam hal ini pengusaha dapat mengetahui keinginan dan selera konsumennya serta gaya hidupnya dan dengan demikian maka pengusaha dapat menyesuaikan cara pendekatan atau komunikasinya dengan konsumen itu secara lebih tepat yang sesuai dengan konsumen yang bersangkutan. Kegiatan yang termasuk dalam kategori personal selling adalah (1) Door to door Selling, (2) Mail Order, (3) Telephone Selling, dan (4) Direct Selling. Publisitas (Publication), merupakan cara yang biasa digunakan juga oleh pengusaha untuk membentuk pengaruh secara tidak langsung kepada konsumen agara mereka menjadi tahu dan menyenangi produk yang dipasarkannya. Cara ini dilakukan dengan cara memuat berita tentang produk atau perusahaan yang menghasilkan produk tersebut di mass media, misalnya berita di surat kabar, berita di radio atau televisi maupun majalah tertentu dan sebagainya.

\section{METODE PENELITIAN}

Penelitian ini menggunakan metode penelitian deskriptif dengan analisis data secara kualitatif, data yang diolah ada dua jenis, yaitu data primer dan data sekunder. Data primer diperoleh secara langsung dari informan yang dijadikan subjek penelitian. Sementara data sekunder diperoleh melalui studi dokumentasi. Ada 6 orang yang dijadikan sebagai subjek penelitian, yaitu 1). Manager, 2). Kepala Bagian Perkreditan, 3). Kepala bagian Pemasaran, dan 4). 2 orang anggota CU. Penentuan subjek penelitian menggunakan teknik Purposive Sampling (subjek penelitian 1 3) dan Incidental Sampling (2 orang anggota). Teknik pengumpulan data menggunakan teknik wawancara, observasi, dan dokumentasi.

\section{HASIL DAN PEMBAHASAN Produk}

Produk pinjaman merupakan produk jasa keuangan sebagai urat nadi usaha bisnis lembaga keuangan baik bank maupun non bank. Salah satu lembaga keuangan yang membidangi jasa keuangan dibidang pinjaman atau perkreditan adalah CU Keling Kumang. Sebagai lembaga keuangan, ada dua dimensi usaha pokok yang dikembangkan, yaitu menghimpun dana dari masyarakat berupa tabungan dan menyalurkan dana yang terhimpun kepada masyarakat lain yang memerlukan dana berupa pinjaman (kredit). Pinjaman merupakan usaha pokok untuk mendapatkan keuntungan, yaitu berupa selisih antara pendapatan dari bunga pinjaman dengan biaya - biaya yang dikeluarkan yang antara lain secara garis besar terdiri dari biaya bunga tabungan anggota dan biaya - biaya operasional.

Berdasarkan data hasil penelitian produk pinjaman CU Keling Kumang memiliki kententuan umum sebagai berikut :1. Untuk dapat mengajukan pinjaman, seseorang anggota harus sudah menjadi anggota penuh dengan melunasi semua persyaratan menjadi anggota penuh, kecuali peminjam harian. 2. Sudah mengikuti pendidikan dasar dengan menunjukkan kartu peserta Pendidikan Dasar. 3. Usia peminjam minimal 17 tahun atau maksimal 65 tahun. 4. Saat akad kredit kondisi peminjam dalam keadaan sehat jasmani dan rohani. 5 . Bersedia melunasi iuran gedung (bagi yang belum lunas) sebesar Rp 100.000,- dan dapat dipotong dari pencairan pinjaman. 6 . Untuk pinjaman diatas modal bersedia di investigasi kredit langsung ke rumah. 7. Wajib melampirkan hasil check-up kesehatan khusus pinjaman di atas Rp 500 juta dan peminjam yang diminta pihak asuransi.Biaya check-up kesehatan ditanggung oleh peminjam. Apabila tidak mengikuti standar ini maka resiko ditanggung oleh peminjam dan ahli waris, dibuktikan dengan surat pernyataan. 1. Biaya investigasi diluar wilayah pengembangan CU Keling Kumang di tanggung oleh calon peminjam walaupun pinjaman tidak setujui. 2. Saldo Simpanan yang dijadikan jaminan pinjaman tidak dapat ditarik secara tunai selama pinjaman belum lunas. 3. Rasio hutang (hutang di CU Keling Kumang dan di tempat lain) $=30 \%$ dari pendapatan. (angsuran pinjaman di CU Keling Kumang dan ditempat lain maksimum 30\% dari pendapatan). 4. Tanggal jatuh tempo angsuran pinjaman (angsuran pokok + bunga) sama dengan tanggal pencairan pinjaman atau sesuai dengan perjanjian pinjaman. 5. Jika terjadi tunggakan 
pinjaman dikenakan denda sebesar $3 \%$ dari angsuran dan bunga pinjaman tertunggak. 6 . Keputusan Kredit menggunakan analisis $5 \mathrm{C}$ (Kemampuan Mengembalikan, Watak, Barang Jaminan, Modal, Kondisi). Untuk pinjaman diatas modal memerlukan minimal 1 orang pemberi referensi. CU KK memberikan perlindungan asuransi pinjaman (APIN) maksimal Rp 100.000.000,- Semua pinjaman di atas $\mathrm{Rp}$ 100.000.000,- wajib membayar premi asuransi. Mengisi Surat Permohonan Pinjaman dengan melampirkan: Photokopi KTP suami dan istri atau Surat Keterangan Domisili. Photokopi Kartu Keluarga. Apabila poin 17.1 dan 17.2 tidak ada, maka diganti dengan Surat Keterangan Kependudukan. Buku SISKA suami/istri bagi yang sudah menikah. Semua ketentuan lebih lanjut mengenai pinjaman dituangkan dalam SOP kredit

Adapun jenis - jenis produk pinjaman/kredit yang dimiliki oleh CU Keling Kumang adalah sebagai berikut :

\section{Pinjaman Produktif}

Produk pinjaman produktif merupakan jenis pinjaman yang diperuntukan bagi peminjam (debitur) yang memerlukan dana untuk berbisnis, mengembangkan usaha, dan keperluan - keperluan lain yang sifatnya produktif. Adapun ketentuan mengenai tingkat bunga, plafon kredit dan jangka waktu dan jenis pinjaman produktif di cantumkan pada tabel 4.6.

Tabel 1. Karakteristik Produk Pinjaman Produktif

\begin{tabular}{|c|l|r|r|c|}
\hline N0 & \multicolumn{1}{|c|}{ JENIS PINJAMAN } & \multicolumn{1}{|c|}{ PLAFON(Rp) } & \multicolumn{1}{c|}{ BUNGA } & JASA PELAYANAN \\
\hline 1 & Usaha (barang dan jasa) & 500.000 .000 & $1,75 \% \mathrm{M}$ & $1,5 \%$ \\
\hline 2 & Khusus & 2.000 .000 .000 & $1,5 \% \mathrm{M}$ & $2 \%$ \\
\hline 3 & Kelompok & 3.000 .000 .000 & $1,5 \% \mathrm{M}$ & $1,5 \%$ \\
\hline 4 & Rumah ibadah & & $1 \% \mathrm{M}$ & $1,5 \%$ \\
\hline 5 & Pinjaman Harian & 10.000 .000 & $4 \% \mathrm{~T}$ & $2 \%$ \\
\hline 6 & Karet dan Sawit & 10.000 .000 & $1,2 \% \mathrm{M}$ & $1 \%$ \\
\hline
\end{tabular}

Sumber : Pola Kebijakan (POLJAK) CU Keling Kumang 2016
Berdasarkan data pada tabel 1 terdapat enam kelompok utama yang termasuk jenis pinjaman produktif dengan plafon, bunga dan jasa pelayanan yang bervariasi. Plafon menunjukkan bahwa batas pinjaman paling tinggi yang dapat diberikan oleh lembaga kepada peminjam. Bunga dengan persentase tertentu mulai dari $1 \%$ sampai $1,75 \%$ Menurun (M) dan khusus pinjaman harian bunga $4 \%$ (empat persen sistem bunga tetap). Bunga pinjaman merupakan biaya yang harus dikeluarkan oleh peminjam dan disetorkan ke lembaga $\mathrm{CU}$, dan bagi lembaga bunga yang disetor peminjam merupakan sumber pendapatan. Selain bunga pinjaman yang menjadi biaya bagi peminjam adalah jasa pelayanan dan bagi lembaga juga merupakan pendapatan.

Jenis pinjaman produktif kategori usaha barang dan jasa merupakan pinjaman yang bertujuan untuk mengembangkan usaha yang sudah ada, dan jumlah pinjaman yang dapat diberikan oleh pihak CU sebesar $70 \%$ dari total nilai usaha yang sudah ada. Sementara yang dimaksud dengan pinjaman khusus adalah adalah pinjaman untuk tujuan produktif dalam jumlah besar seperti proyek jalan, jembatan, perkantoran dan lain sebagainya). Selanjutnya pinjaman kelompok, pinjaman kelompok diperuntukan bagi kelompok atau unit usaha tertentu yang dimiliki lebih dari satu orang. Berikutnya jenis pinjaman harian, yaitu diperuntukan bagi para pedagang kecil, seperti pedagang kaki lima dan para pedagan di pasar sayur dengan cara pembayaran dilakukan setiap hari kerja. Jenis pinjaman produktif yang lain adalah untuk pinjaman yang bertujuan untuk membangun rumah ibadah dan perkebunan baik karet maupun sawit.

\section{Pinjaman Konsumtif}

Jenis pinjaman konsumtif, sesuai dengan namanya adalah jenis pinjaman yang peruntukannya untuk membeli barang-barang yang bersifat pemenuhan kebutuhan multi guna dan kendaraan bukan untuk usaha. Karakteristik 
mengenai produk pinjaman konsumtif dapat dilihat pada tabel 2 .

Tabel 2 Karakteristik Produk Pinjaman Konsumtif

\begin{tabular}{|l|l|r|r|c|}
\hline $\mathrm{N} 0$ & JENIS PNJAMAN & PLAFON(Rp) & BUNGA & JASA PELAYANAN \\
\hline 1 & Sepeda Motor & 30.000 .000 & $1,5 \% \mathrm{M}$ & $1,5 \%$ \\
\hline 2 & Speed Boat & 40.000 .000 & $1,5 \% \mathrm{M}$ & $1,5 \%$ \\
\hline 3 & Mobil & 400.000 .000 & $1,5 \% \mathrm{M}$ & $1,5 \%$ \\
\hline 4 & Multi Guna & 100.000 .000 & $2 \% \mathrm{M}$ & $1,5 \%$ \\
\hline
\end{tabular}

Sumber : Pola Kebijakan (POLJAK) CU Keling Kumang 2016

Pinjaman untuk jenis konsumtif kategori multi guna merupakan pinjaman untuk berbagai keperluan hidup seperti untuk pembelian barang perabot rumah tangga, biaya pernikahan, rehap rumah, dan lain-lain.

\section{Pinjaman Kepemilikan Rumah (KPR)}

Pinjaman KPR merupakan kredit yang bertujuan untuk membeli rumah, dan kavling tanah dengan maksimal pinjaman sebesar satu miliar rupiah. Persyaratan untuk mendapatkan pinjaman ini adalah : 1). Material bangunan sudah tersedia $40 \%$, 2). Sudah menjadi anggota CU minimal tiga tahun, 3). Memiliki tabungan jenis kepemilikan rumah minimal $10 \%$, 4). Agunannya adalah rumah yang dibeli. Bunga pinjaman KPR sebesar 1,2\% menurun, jasa pelayanan 1,5\% dengan jangka waktu pinjaman paling lama 180 bulan (15 tahun).

\section{Pinjaman Pendidikan}

Pinjaman pendidikan bertujuan untuk memfasilitasi bagi pelajar dan mahasiwa yang sedang menempuh pendidikan ataupun bagi mereka yang memerlukan dana untuk melanjutkan kejenjang pendidikan yang lebih tinggi berikutnya. Plafon, bunga, dan jasa pelayanan pinjaman pendidikan dapat dilihat pada tabel 4.8.
Tabel 3 Karakteristik Produk Pinjaman Pendidikan

\begin{tabular}{|c|l|r|r|c|}
\hline N0 & Jenis Pendidikan & \multicolumn{1}{|c|}{ Plafon $(\mathrm{Rp})$} & \multicolumn{1}{c|}{ Bunga } & Jasa Pelayana \\
\hline 1 & SMU & 7.000 .000 & $1 \% \mathrm{M}$ & $2 \%$ \\
\hline 2 & PolisiTentara & 50.000 .000 & $1 \% \mathrm{M}$ & $2 \%$ \\
\hline 3 & Akademi & 20.000 .000 & $1 \% \mathrm{M}$ & $2 \%$ \\
\hline 4 & Universitas & 30.000 .000 & $1 \% \mathrm{M}$ & $2 \%$ \\
\hline
\end{tabular}

Sumber : Pola Kebijakan (POLJAK) CU Keling Kumang 2016

Adapun persyaratan untuk mendapatkan kredit/pinjaman pendidikan adalah sebagai berikut

1) Mengisi formulir permohonan pinjaman dengan melampirkan photo copy Kartu Keluarga.

2) Melampirkan buku rekening Takan plus (tabungan pendidikan) dan memiliki saldo Takan minimal Rp 1 juta dan sudah mengendap minimal 6 bulan.

3) Melampirkan bukti lulus tes pendidikan.

4) Dicairkan sekaligus, tetapi dibawa pulang sesuai keperluan pendidikan dan sisanya yang belum dibutuhkan saat itu sementara disimpan di Takan.

5) Pelajar atau mahasiswa yang bersangkutan sudah menjadi anggota SISKA (simpanan sukarela) dan Takan.

6) Pinjaman harus atas nama orang tua yang bersangkutan, kecuali yang sudah kerja.

7) Melaporkan transkrip nilai setiap semester, kecuali sekolah polisi/tentara.

8) Orang tua sudah menjadi anggota penuh paling tidak 1 tahun.

9) Dilindungi oleh Asuransi Pinjaman (APIN).

10) Seluruh keluarga inti (bapak, Ibu, kakak, $\&$ adik) sudah menjadi anggota SISKA.

5. Pinjaman Kapitalisasi

Pinjaman kapitalisasi adalah jenis pinjaman untuk menambah saldo tabungan, artinya, pinjaman 
yang dicairkan uangnya tidak dibawa pulang, melainkan tetap di CU dan dimasukan ke tabungan. selain itu yang termasuk pinjaman kapitalisasi adalah jumlah pinjaman yang diajukan lebih kecil daripada saldo tabungan sendiri dan keluarga inti yang ada di CU dan uang tunainya dibawa pulang. Pinjaman kapitalisasi dikenakan bunga 1,2\% menurun, jasa pelayanan $1 \%$, dan jangka waktu pinjaman paling lama 60 bulan (lima tahun). Tujuan pinjaman kapitalisasi adalah sebagai salah satu cara agar anggota dapat dengan cepat mencapai jumlah tabungan yang besar dengan jumlah tertentu yang diinginkan, karena bila dengan menabung dari penyisihan uang perbulan dari penghasilan rata - rata anggota sulit untuk menabung dalam jumlah yang besar. Saldo tabungan yang besar dapat berkembang lebih cepat karena bunga tabungan yang diberikan lembaga nominalnya juga besar berkembang secara proporsional dengan besarnya saldo tabungan.

\section{Pinjaman Rendah bunga (Rebung)}

Pinjaman rendah bunga diperuntukan bagi anggota CU Keling Kumang yang kurang mampu secara ekonomi, yaitu mereka yang memiliki penghasilan dibawah Rp. 1.500.000,per bulan. Pinjaman rebung hanya dibebankan bunga sebesar $0,5 \%$ menurun, jasa pelayanan $1 \%$, plafon maksimal pinjaman yang dapat diberikan sebesar Rp. 3.000.000,-. Dengan adanya pinjaman jenis ini masyarakat yang kurang mampu atau berpenghasilan rendah diharapkan dapat memanfaatkannya untuk tujuan yang produktif sehingga perekonomian masyarakat dapat meningkat dari yang tadinya kurang mampu menjadi berdaya dan selanjutnya dapat hidup layak dan menjadi sejahtera.

Berdasarkan hasil wawancara dengan subjek penelitian, jenis produk pinjaman konsumtif lebih dominan diminati oleh anggota CU Keling Kumang. Hal ini menunjukkan masih dominannya gaya hidup konsumtif pada masyarakat. Pola konsumsi seperti ini berpengaruhi terhadap perkembangan perekonomian yaitu sulit untuk lebih mengembangkan produktifitas aset yang dimiliki. Motivasi untuk mengembangkan investasi masih rendah. Sementara investasi, seperti menabung, membuka usaha, dan membeli harta tetap seperti tanah sangat penting untuk jangka panjang. Di sisi lain, bahwa kendala utama dalam pelayanan kredit adalah masih rendahnya tingkat pemahaman anggota terhadap persyaratan yang harus dipenuhi sehingga kekurang pahaman ini terkadang menyebabkan anggota berpikiran negatif dan tidak simpatik terhadap lembaga, apalagi bila pinjamannya tidak dikabulkan karena tidak memenuhi persyaratan kredit. Akibat selanjutnya tidak jarang anggota yang kurang pemahaman dan kesadaran tersebut akhir memutuskan untuk tutup rekening dan keluar dari keanggotaan. Berdasarkan dinamika yang berkembang, ada beberapa kelompok usaha produktif yang menginginkan cara pengembalian kredit (pinjaman) waktu pengembaliannya setelah masa panen tiba, misalnya usaha keramba ikan dan beberapa jenis tanaman perkebunan musiman. Anggota sebenarnya memiliki kemampuan mengembalikan setelah masa panen ikan tiba, karena masa pembesaran sebelum panen masih memerlukan biaya dan belum ada pemasukan.

Selanjutnya berkaitan dengan kendala pemasaran produk adalah faktor eksternal berupa persaingan dengan lembaga keuangan lain, seperti misalnya bank yang terkadang memiliki suku bunga rendah dibandingkan CU, hal ini pasti memiliki dampak dalam hal pemasaran. Walau demikian, produk CU juga banyak kelebihannya, karena anggota bisa mengangsur pinjaman sambil menabung untuk memperbesar saldo tabungan. Keunggulan menabung di CU adalah sampai saat ini belum dikenai pajak oleh pemerintah, hal ini karena pertimbangan bahwa tabungan $\mathrm{CU}$ adalah kumpulan dari anggota yang berasaskan koperasi yang dibangun dengan kesadaran dari masyarakat kurang mampu dengan misi utama adalah pemberdayaan ekonomi masyarakat pedesaan. Pembebanan pajak hanya dikenakan pada pajak penghasilan lembaga berdasarkan laba penghasilan yang diperoleh per periode akuntansi. 


\section{Harga (Price)}

Harga berarti nilai dari suatu barang maupun jasa yang dalam penelitian ini di hitung berdasarkan nilai mata uang rupiah. Dengan demikian untuk mendapatkan jasa pelayanan pinjaman dan sejumlah nominal uang yang didinginkan untuk dipinjam oleh anggota $\mathrm{CU}$, maka si debitur (penerima kredit) harus membayar sejumlah uang sebesar nilai yang ditetapkan oleh kreditur atau lembaga CU sebagai pemilik produk. Faktor faktor yang menjadi harga di dalam produk pinjaman antara lain jasa pelayanan pinjaman, materai, dan tentunya bunga pinjaman itu sendiri. Berdasarkan ketentuan pola kebijakan pengurus, jasa pelayanan ditetapkan sebesar satu persen dari total pinjaman yang diajukan, materai satu buah yang digunakan untuk perjanjian pinjaman yang dibubuhkan pada surat perjanjian pinjaman. Bunga pinjaman berkisar antara 1 persen sampai 2 persen tergantung jenis pinjaman. Secara garis besar, pendapatan lembaga diperoleh dari selisih antara pendapatan bunga kredit dengan bunga tabungan yang menjadi hak anggota. Setiap produk berbeda persentase bunga pinjamannya yang disesuaikan dengan bunga tabungan, sesuai jenis produk masing - masing.

sistem perhitungan bunga pinjaman ada dua pilihan yang dapat diambil oleh anggota, yaitu sistem bunga flat (sistem bunga tetap) dan sitem bunga Anuitas (sistem bunga menurun tetap). Sistem pembungaan tetap adalah biaya bunga yang harus dibayar/disetor oleh peminjam yang jumlahnya tetap setiap bulannya. Besaran bunga pinjaman tersebut didapat dari perkalian antara jumlah pokok pinjaman dikalikan dengan ketetapan persentase bunga yang diterapkan kemudian dibagi dengan jumlah bulan pengembalian pinjaman tersebut. Jumlah uang yang harus disetor terdiri dari bunga pinjaman dan angsuran pokok pinjaman. Sementara itu sistem bunga menurun tetap atau anuitas adalah sistem perhitungan bunga pinjaman yang besarnya setiap bulan akan menurun atau mengecil. Cara perhitungannya adalah sisa saldo pinjaman pada bulan pengangsuran dikalikan ketetapan bunga. Kemudian jumlah angsuran diperbesar setiap bulannya untuk sesuai dengan besaran penurunan bunga setiap bulannya.

Berdasarkan wawancara dengan subjek penelitian bahwa anggota yang meminjam lebih banyak memilih sistem pembungaan menurun, dengan alasan bahwa secara kumulatif sistem bunga tersebut lebih kecil bila dibandingkan dengan sistem perhitungan bunga tetap. Namun bedanya dengan sistem bunga tetap, sistem bunga menurun pada bulan awal pengansuran pinjaman jumlah yang harus disetorkan tentu jauh lebih besar bila dibandingkan dengan cara sistem bunga tetap. Terdapat beberapa biaya yang harus dikeluarkan pada saat pencairan pinjaman yaitu biaya administrasi pinjaman yang besarnya $1 \%$ dari total pinjaman yang dicairkan. Biaya tersebut dipotong langsung dari pinjaman cair, sehingga jumlah tunai pinjaman yang diterima tidak penuh atau tidak sebesar jumlah pinjaman, selain itu ada potongan 5 - $10 \%$ dari total pinjaman dialokasikan untuk menambah saldo tabungan yang ada. Mengingat untuk dapat mengajukan pinjaman, seseorang haruslah menjadi anggota terlebih dahulu dan memiliki tabungan yang sesuai untuk dapat dikabulkan pinjamannya. Diluar anggota untuk sementara tidak dapat mengajukan pinjaman.

\section{Tempat (Place)}

Tempat dalam konsep pemasaran merupakan suatu lokasi dimana dilangsungkannya aktivitas transaksi jual beli. Transaksi di lembaga $\mathrm{CU}$ tentu transaksi bukan barang, melainkan transaksi jasa keuangan. Tempat pemasaran tersebut dapat berupa bangunan gedung (indoor) maupun ditempat terbuka (outdoor) atau dimanapun dilakukannya interaksi pemasaran antara pihak pengelola $\mathrm{CU}$ dengan pihak anggota. Aspek tempat menjadi penting di dalam sub sistem pemasaran. Karena tempat dapat mempengaruhi tingkat harga. Oleh karena itu kantor sebagai tempat dan pengendali utama kegiatan pelayanan menjadi sangat penting keberadaannya dalam menentukan gerak langkah kegiatan operasional bisnis jasa keuangan. Keamanan dan kenyaman 
dalam melakukan pelayanan oleh manajemen menjadi hal yang penting dan tidak dapat diabaikan oleh pengambil keputusan. begitu juga bagi para anggota, mereka tentu akan merasakan lebih nyaman dan betah dengan tempat pelayanan yang kondusif, sesuai dengan lingkungan yang diinginkan masyarakat.

Berdasarkan hasil wawancara dengan subjek penelitian bahwa tempat pemasaran produk CU Keling Kumang sudah memiliki tempat berupa kantor, baik untuk kegiatan administrasi maupun pelayanan keanggota yang sudah dianggap cukup representatif. Pembangunan lebih mempertimbangkan kelancaran akses ke berbagai stakeholder terkait. Selain kantor pusat dibangun juga kantor-kantor pelayanan pembantu yang didirikan di desa-desa. Khusus untuk wilayah yang dapat dijangkau dengan kendaraan darat, baik kendaraan roda dua maupun roda empat, hampir tidak menemui kendala. Namun untuk daerah yang harus dijangkau dengan jalur sungai, biaya menjadi transportasi menjadi mahal karena tranportasi sungai lebih banyak menghabiskan bahan bakar minyak.

\section{Promosi (promotion)}

Kegiatan promosi sangat penting agar produk yang diproduksi atau disediakan oleh sebuah lembaga bisnis dapat diketahui dan selanjutnya timbul minat konsumen untuk memilikinya. Promosi di lembaga Credit Union merupakan program kerja yang dilakukan secara rutin baik dalam periode jangka pendek maupun jangka panjang. Periode jangka pendek meliputi kegiatan promosi yang dilakukan secara rutinitas sehari - hari, bulanan, atau per semester. Sementara promosi yang dilakukan dalam periode jangka panjang merupakan promosi yang dilaksanakan bisa dilakukan hanya satu tahun sekali bahkan lebih dari satu tahun. Salah satu even promosi yang dilakukan tahunan adalah kegiatan Rapat Anggota Tahunan, walaupun acara Rapat Anggota Tahunan bukan dirancang khusus untuk kegiatan promosi, namun secara tidak langsung acara di dalam RAT mengandung unsur - unsur promosi, mengingat banyak rangkaian kegiatan yang sifatnya memperkenalkan keunggulan produk - produk yang dimiliki, termasuk juga produk yang baru yang akan diluncurkan pada tahun buku berikutnya. Kegiatan promosi lain yang dilaksanakan di CU adalah dengan cara memberikan brosur - brosur kepada anggota dan calon anggota. Lebih lanjut dijelaskan oleh Kepala Bagian perkreditan, bahwa strategi promosi yang dilakukan oleh staf Loan officer dalam hal promosi produk pinjaman adalah dengan cara mencari dan menawarkan pinjaman kepada anggota yang potensial. Cara ini sangat baik untuk menyalurkan kredit agar uang yang dipinjaman ke anggota dapat beredar dan berputar dengan cepat sehingga keuntungan lembaga dari pendapatan bunga dapat lebih besar. Faktor yang masih menjadi hambatan di dalam melaksanakan promosi adalah sarana dan prasarana yang masih terbatas serta sumber daya pegawai juga masih belum maksimal dalam mengembangkan dan melaksanakan promosi. Walau demikian, sumber daya manusia pegawai yang ada saat ini sudah memiliki kemampuan, loyalitas, dan komitmen yang lumayan baik, hanya saja masih ada kekurangannya sehingga pelaksanaan promosi belum optimal.

\section{KESIMPULAN DAN SARAN}

Berdasarkan uraian pada hasil dan pembahasan, maka penelitian ini dapat disimpulkan sebagai berikut : Aspek produk, CU Keling Kumang memiliki enam jenis produk pinjaman yaitu pinjaman produktif, konsumtif, pendidikan, kapitalisasi, Kapitalisasi, dan Pinjaman Rendah Bunga (Rebung). Diantara jenis pinjaman tersebut, jenis pinjaman yang lebih banyak diminati oleh anggota adalah pinjaman konsumtif. Aspek harga, produk pinjaman CU Keling Kumang memiliki variasi bunga mulai dari $1 \%$ sampai $2 \%$ dengan sistem bunga flat dan sistem bunga anuitas. Berdasarkan hasil penelitian anggota lebih banyak memilih sistem bunga anuitas. Aspek tempat, strategi untuk memudahkan pelayanan CU Keling Kumang membangun kantor Cabang di pusat Kota Kabupaten Kapuas Hulu, yaitu di kota Putussibau, kantor tersebut sudah representatif, selain itu dibentuk pula Staf Loan Officer yang menanggani 
wilayah kerja masing - masing untuk urusan perkreditan. Aspek promosi, CU Keling Kumang dalam memperkenalkan dan menumbuhkan minat anggota dan calon anggota dengan cara memberikan brosur - brosur, melaksanakan pendidikan $\mathrm{CU}$, dan dengan cara datang ke rumah - rumah terutama mendatangi anggota yang potensial.

Disarankan hal-hal sebagai berikut: Berdasarkan aspek produk, kedepannya dapat dipertimbangkan untuk merancang produk pinjaman dengan sistem pengangsuran atau pembayaran setelah usaha produktif menghasilkan (yaitu pada masa paska panen). Berdasarkan aspek harga,

\section{DAFTAR PUSTAKA}

Alma, B. 2005. Kewirausahaan. Bandung : Alfabeta.

Alma, B. 2007. Manajemen Pemasaran \& Pemasaran Jasa, Bandung : CV. Alfabeta. Bandung.

Gitosudarmo H. Indriyo, 2001. Manajemen Strategis, PT. BPFE Yogyakarta.

Gitosudarmo H. Indriyo, 2001. Prilaku Keorganisasian, Cetakan Ketiga. Jogyakarta : BPFE.

Hurriyati, 2008. Bauran Pemasaran dan Loyalitas Konsumen, Alfabeta, Bandung.

Kasmir, 2013. Dasar - Dasar Perbankan, PT. Raja Grafindo Persada, Jakarta.

Kotler Philip dan Keller 2009. Manajemen Pemasaran Jilid 1 PT. Gramedia Pustaka Utama, Jakarta.

Kotler Philip, 2007. Manajemen Pemasaran, edisi 11, jilid 1, PT. Gramedia Pustaka Utama, Jakarta.

Laksana, F. 2008. Manajemen Pemasaran Pendekatan Praktis edisi pertama: Graha Ilmu Yogyakarta. bunga pinjaman sudah cukup rendah, namun kedepannya dapat diturunkan lagi mengingat bunga pinjaman perbankan juga rata - rata lebih rendah, hal ini untuk meningkatkan daya saing di pasaran keuangan. Berdasarkan aspek tempat, kedepannya dapat diperbanyak lagi pos - pos pelayanan di kampung - kampung yang jauh dari kantor, supaya lebih memudahkan pelayanan kepada anggota. Berdasarkan aspek promosi, kedepannya sebaiknya dapat ditingkatkan lagi baik kuantitas maupun kompetensi dari pegawai yang melaksanakan promosi agar penyadaran masyarakat akan pentingnya ber-CU dapat lebih cepat dan lebih banyak yang menjadi anggota.

Molan B. 2007. Manajemen Pemasaran, Edisi Kedua belas, Jilid 1, Jakarta : PT. Indeks.

Moleong,L.J.1991. Metode Penelitian Kualitatif. Bandung: PT. Remaja Rosdakarya.

Nasution, M. 1999. Metode Penelitian Naturalistik Kualitatif. Bandung: PT. Remaja Rodakarya.

Nasution, M. 2004. Manajemen Jasa Terpadu, Bogor; Ghalia Indonesia.

Nasution, M. 2006. Manajemen Industri. Yogyakarta; Andi.

Ratih Hurriyati. 2008, Manajemen Corporate dan Strategi Pemasaran Jasa Pendidikan. Bandung: Alfabeta.

Saladin Djaslim, 2007. Manajemen Pemasaran, Bandung ; Linda Karya.

Triana, Alex. D. 1985. Menerapkan Strategi Marketing Di Indonesia. Marketing Seminars.

Peraturan Perundang - Undangan :

Undang-Undang No.10 Tahun 1998 tentang Perbankan 